\title{
Management of financial and economic development of border regions of Ukraine
}

\author{
KATERYNA I. MALINOSHEVSKA ${ }^{1}$, DENYS MARTYSHYN ${ }^{2}$, INGA PERESTYUK ${ }^{3}$, \\ SVITLANA PANCHENKO ${ }^{4}$, AZAD OMAROV $^{5}$
}

\author{
${ }^{1}$ «Highline Media» Ltd, UKRAINE \\ ${ }^{2}$ Department of Ukrainian Studies, Orthodoxy and Theology Interregional Academy of Personnel \\ Management, UKRAINE \\ ${ }^{3}$ Interregional Academy of Personnel Management, UKRAINE \\ ${ }^{4}$ Department of Cultural Studies and Information Communications, National Academy of Managerial \\ Staff of Culture and Arts, UKRAINE \\ ${ }^{5}$ Department of Public Administration, Interregional Academy of Personnel Management, UKRAINE
}

\begin{abstract}
The aims of the research are to study the management efficiency of financial and economic development of the border regions of Ukraine through the assessment of funding of the Cross-Border Cooperation Programme Poland-Belarus-Ukraine 2014-2020. The methodology is based on quantitative and qualitative research following the concept of "cross-border regional innovation system". The basic research methods are statistical analysis of project financing indicators of the Cooperation Programme and content analysis of reports for 2016-2019 on project implementation. The results demonstrate the crucial role of the proximity of border regions in the level of development of the social-economic system, which accelerates cross-border cooperation and the effects of integration. Quantitative and qualitative assessments of the Programme prove the existence of insignificant short-term effects of cooperation between countries due to different levels of development of the border regions of Ukraine and Poland. The higher level of economic development of Poland's regions has provided a comparative advantage in the implementation of projects in the framework of the Programme. The formation of a market model of Ukraine's economy determines the implementation of projects in the social sphere, which in the long run will provide an influx of investment. The practical significance of the results lies in the possibility of using the results of the study in the development of cross-border cooperation programs within the concept of "cross-border regional innovation system".
\end{abstract}

Key-Words: - Border Regions, Financial and Economic Development of Regions, Cross-Border Cooperation Poland-Ukraine, Management of Border Regions

Received: September 2, 2021. Revised: March 3, 2021. Accepted: March 12, 2021. Published: March 26, 2021.

\section{Introduction}

In the context of decentralization, integration and convergence of development of Ukraine's border regions in accordance with EU practice, the system of public administration of border areas is transformed [1]. This causes a change in approaches to managing the financial and economic development of border regions. Management moves from the national to the local level, with strategic planning of cross-border cooperation at the national level. As a result, regional development projects of various scales are being implemented within the framework of cross-border cooperation [2]. This leads to a different degree of influence on the financial and economic development of border regions.

The aims of the research are to study the management efficiency of financial and economic development of the border regions of Ukraine through the assessment of funding of the CrossBorder Cooperation Programme Poland-BelarusUkraine 2014-2020. The object of study of this academic paper is the management efficiency of financial and economic development of the border regions of Ukraine. This involves assessing funding (financial flows in the form of investments) and stimulating innovation as a little studied subject of cross-border cooperation. 


\section{Literature Review}

The scientific literature discusses four basic issues of development of border regions, namely: (1) cooperation and integration; (2) regional (economic) development; (3) governance, policy and politics; and (4) mobility: migration, tourism and labour markets $[3 ; 4 ; 5]$. Other subjects of research include: globalization, reorganization, ethnicity and identity.

Interest in the study of the issue is growing, in particular in 2000-2013 [3]; it focuses in general on the regions of Europe and North America, where integration processes and cooperation are most common. Recent investigations examine crossborder cooperation in the Asian region, in particular on the example of China [6;7]. Hameiri, Jones \& Zou prove that the integration of China and Myanmar has increased insecurity, ethnic conflicts in border areas, led to a crisis of bilateral relations due to a predatory form of cooperation in the regions [6]. Günther, Latifi, Lubacha-Sember \& Töbelmann prove the increase in the frequency and intensity of joint scientific activities of Poland and Germany as a result of cooperation [8].

In general, the researchers are based on the study of case-studies and form the conceptual basis for the development of cross-border cooperation. (Figure1).

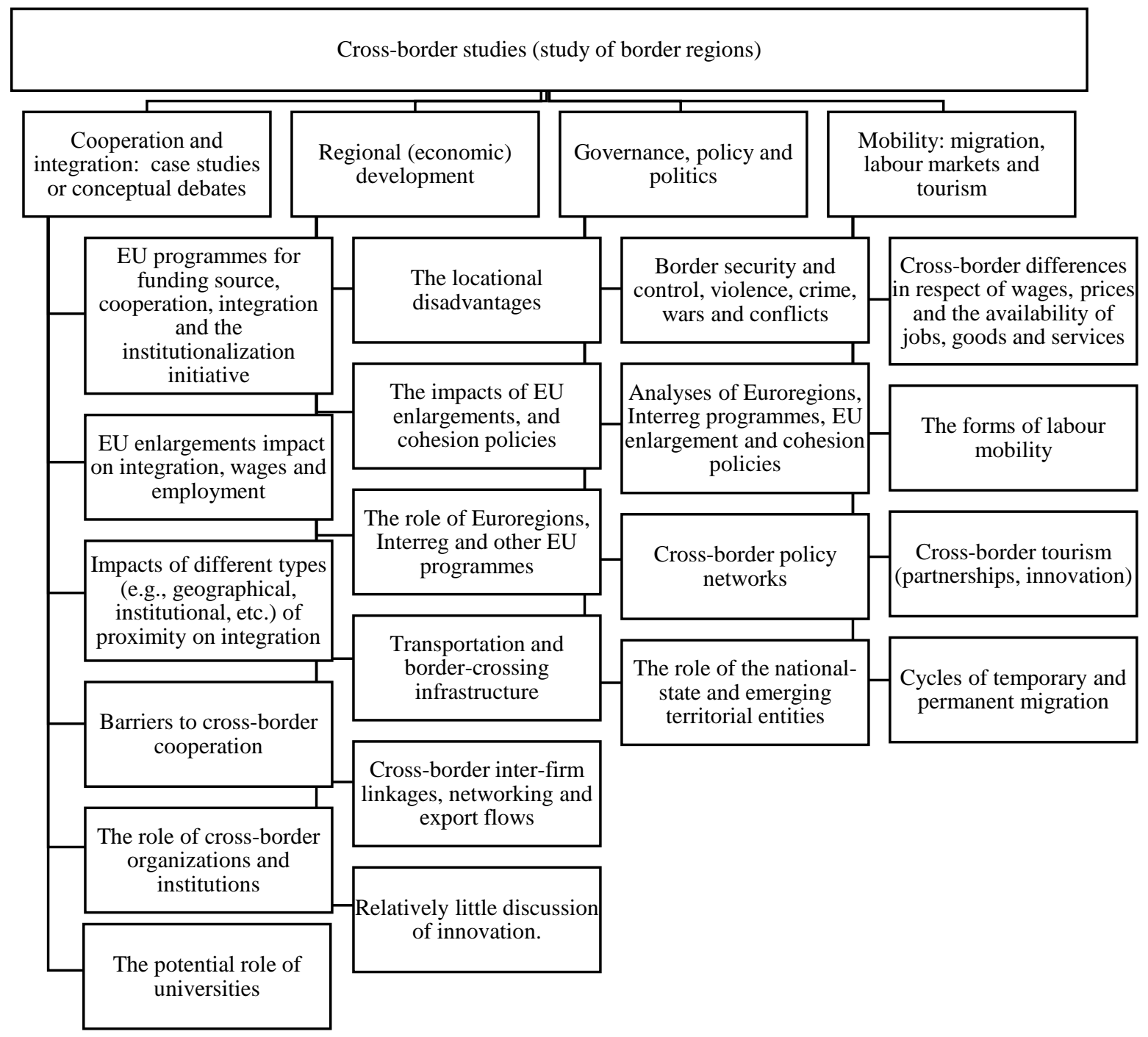

Source: $[3 ; 9 ; 11 ; 12]$

Fig. 1. Subjects of research of border regions

For instance, Klatt studies "Border regions as laboratories of European integration" and draws conclusion concerning stability of borders as a physical expression of state sovereignty in the complex reality of joint sovereignty between EU members and supranational institutions [9].

At the same time, comparative quantitative and qualitative assessment of barriers are little studied in 
the scientific literature [10], as well as drivers of integration processes within the border regions, in particular the impact of innovation on regional development within the framework of cooperation.

The problematic of managing border regions is usually focused on geographically large objects (Euroregions), while political networks, managerial processes, in particular financial and economic development, have been little studied. For instance, the study of Mendoza \& Dupeyron, based on cases of integration of the cities of San Diego and Tijuana in order to develop economic, social and political relations, has proven the strengthening of problems concerning the management of regional crossborder cooperation [13].

There are almost no studies of innovations, which act as a basic driver of development of border regions in the long run period. Lavrinenko, Jefimovs \& Teivāns-Treinovskis on the basis of qualitative conceptual research have proven that the basic condition for the development of regions in border areas is the effective functioning of the territorial innovation system based on trust between stakeholders [14]. "Gradual expansion of interregional and international ties increases the possibility for synergies, fostering network diversification and intra-regional overspecialisation all at the same time" [15]. The new concept of "cross-border regional innovation system" provides an analysis of the impact of types of regions' proximity (technological, cognitive, etc.) on the cooperation of border regions.

Recent studies pay more attention to drivers of cross-border cooperation. An important element of financial and economic development is financial openness in the process of integration and deepening of cross-border cooperation through improved lending conditions, increasing the number of mergers and acquisitions, as well as increasing investment [7]. Other indicators of financial and economic development of border regions are the costs of consolidated budgets (production, administrative) and expenditures per capita, socially oriented costs [16]. The drivers of economic integration of border regions (cross-border regions, CBR) include: "cognitive proximity, cross-border regional identity, the access to a talented workforce" [17]. In-depth decentralization reforms in Ukraine create an additional opportunity to expand cooperation and financial and economic development of border regions through EU financial support mechanisms and investment growth. The basic tools of integration and financing are international regional development projects, territorial cooperation [1]. Cross-border and international cooperation programs are mechanisms for financing the development of border regions [11]. State financial support for cooperation affects economic development indicators, promotes the formation of networks and increase the level of efficiency of small business [18]. Herewith, the investigation of Nagy has revealed that the financing of cross-border cooperation from EU funds did not increase the local budget of municipalities and local annual GDP, and as a result - significant economic development [19].

The investigation proves the low level of use of such opportunities for the development of border regions of Ukraine due to the inconsistency of regional strategies with the norms of national strategic documents on cross-border cooperation. Some relevant studies can be found in [20] and [21]. In Lviv region, successful projects and programs have been implemented with the support of EU funds and foreign companies through a system of partnership, international and cross-border cooperation, formation of information and communication infrastructure [1].

At the same time, analysis of the scientific literature shows the transition from the study of governance issues, cooperation, regional development, and mobility to the study of drivers of cross-border cooperation. The results of research on the development of border regions contain opposite views: from the growing level of financial and economic development of the studied regions to the lack of positive changes in the field of financial management and regional economy [22]. Such differences can be explained by the new concept of "cross-border regional innovation system", which explains that the kinship of regions in different types of proximity stimulates the development of the regional socio-economic system to a greater extent than in the context of radical differences between regions. Insufficient research on the development of border regions, taking into account the new concept of cross-border regional innovation system determines the need to continue research on the management of financial and economic development of border regions of Ukraine.

The basic hypothesis of their study lies in the fact that the proximity of border regions accelerates cross-border cooperation in terms of the level of development of the social-economic system and the effects of integration. As a result, there are positive effects of cooperation in various areas both in the short and long term periods.

\section{Methodology}




\subsection{Concept and design}

The present study is based on the new concept of "cross-border regional innovation system" and the investment type of proximity of border regions in terms of development level [23]. Forasmuch as the object lies in assessing the financing of cooperation (financial flows in the form of investment in projects), the design of the study is quantitative to a greater extent, taking into account the analysis of investment in border regions by partner countries within cooperation programs. Quantitative analysis is supplemented by qualitative content analysis of reports on the implementation of projects under the Cross-Border Cooperation Programme PolandBelarus-Ukraine 2014-2020 (hereinafter - the Programme).

\subsection{Data and methods}

The regions of Ukraine, Poland and Belarus, namely: Lviv region and Subcarpathian (Podkarpackie) voivodeship (Figure 2), have been selected for the quantitative analysis of the innovative type of proximity of border regions in the framework of the Programme. In order to determine the proximity, the main macroeconomic indicators of regional development have been assessed prior launching the program (2013) and in 2018 (due to the availability of data to compare the two regions).

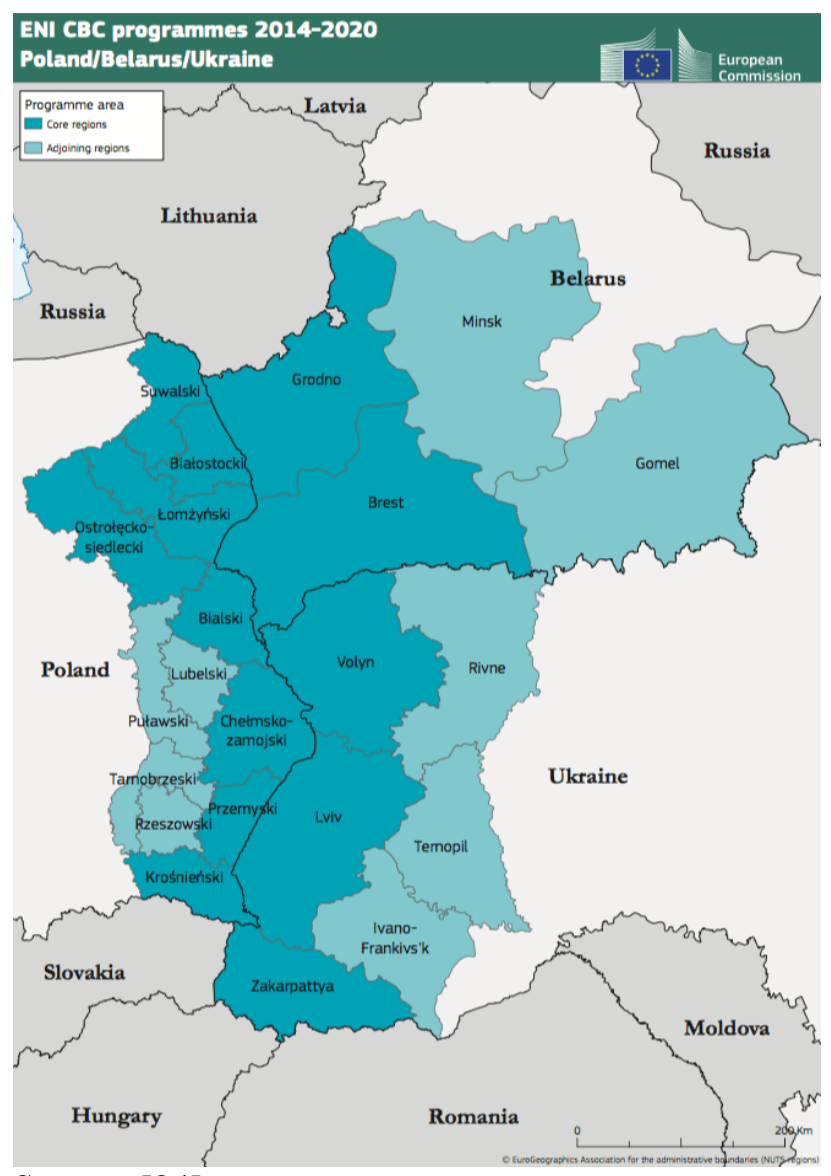

Source: [24]

Fig. 2. The map of border regions within the Poland/Belarus/Ukraine Program

The discrepancies between the main development indicators have been defined as the difference between a certain indicator in 2013 and 2018. Quantitative analysis has been conducted on the basis of indicators: 1) macroeconomic indicators of regional development in 2013 and 2018 (See Table 1); 2) the dynamics of investment in the border regions of Ukraine according to the Main Department of Statistics in Lviv region; 3) the number of projects under the Programme for 2019 and the amount of funding for their implementation.

\subsection{Limitations}

The main problem and limitations of the study lies in the incomparability of data to quantify the management efficiency of financial and economic development of border areas. As a matter of fact, the implementation of the Programme began in 2019, in 2016-2018 the preparatory stages were implemented (trainings, submission of project plans within the Programme and regional development strategies). Therefore, data on the amount of funding and the number of projects within the program for 2019 are 
available for analysis. Data on investments in the border regions of Ukraine, which are participants of the Programme, are available for the period of 20152019, whereas the data on the amount of funding for projects under the Cooperation Programme are available for 2019. There are no data on the investments of Belarus in the Lviv region, which made it impossible to fully assess the effectiveness of financial and economic development of border regions. As a result, the investigation is limited to studying the short-term effects of managing the financial and economic development of border regions.

\section{Results}

\subsection{Innovative similarity of cross-border regions as a basis for financial and economic development}

The program of cooperation between Ukraine, Poland and Belarus provides for the achievement of strategic goals in order to eliminate barriers between countries, promote security and social-economic development by financing non-profit projects. This involves financing $90 \%$ of the costs of project beneficiaries in the form of grants. As a result, border areas will be able to attract investment and create an innovative system in the long run perspective. The effectiveness of cooperation within the Program is evidenced by the basic indicators of cross-border regional development of Ukraine and Poland (see Table 1), which make it possible to assess the proximity of regions according to the concept of "cross-border regional innovation system" [23]. Lviv region and Podkarpackie Voivodeship are similar in area and population, that is, they have the same initial data for the development of cooperation. However, a number of indicators of economic development characterize the differences and inequalities of regional development, namely: 1) the average monthly nominal wage, which determines the level of labour productivity and different human potential, production potential; 2) different level of educational and medical support, which determines the social development and affects the quality of life of the population, the potential for involvement of qualified personnel in the implementation of the Program; 3) different level of tourist attractiveness in favour of Poland; 4) significant lag of Lviv region in terms of economic development and GDP per capita, which characterizes the remoteness of regions in terms of life quality. At the same time, it is worth noting the similarity of the regions in terms of the potential of agricultural sector development and the availability of forests (see Table 1).

Table 1. The basic indicators of development of cross-border regions of Ukraine and Poland (Lviv region, Podkarpackie Voivodeship) in 2013, 2018

\begin{tabular}{|l|c|c|c|c|c|c|}
\hline \multirow{2}{*}{} & \multicolumn{2}{|c|}{ Lviv region } & \multicolumn{2}{c|}{$\begin{array}{c}\text { Podkarpackie } \\
\text { Voivodeship }\end{array}$} & \multicolumn{2}{c|}{$\begin{array}{c}\text { Similarity of } \\
\text { regions }\end{array}$} \\
\cline { 2 - 7 } & 2013 & 2018 & 2013 & 2018 & 2013 & 2018 \\
\hline Area, sq. km & 21831 & 21831 & 17846 & 17846 & -3985 & -3985 \\
\hline Existing population, thousand people & 2538,40 & 2522,00 & 2129,3 & 2129 & -409 & -393 \\
\hline $\begin{array}{l}\text { Natural increase, decrease (-) per 1000 population, } \\
\text { persons }\end{array}$ & $-0,9$ & $-3,8$ & 0,8 & 0,9 & 2 & 5 \\
\hline Unemployment rate according to ILO, \% & 7,1 & 6,9 & 14,3 & 6,5 & 7 & 0 \\
\hline Average monthly nominal wage, Euro & 263 & 249 & 782 & 960 & 519 & 711 \\
\hline $\begin{array}{l}\text { Commissioning of residential premises per 1000 } \\
\text { population, apartments }\end{array}$ & 1,8 & 3,8 & 2,9 & 3,7 & 1 & 0 \\
\hline $\begin{array}{l}\text { Students of higher educational institutions per 10 } \\
\text { thousand population, persons }\end{array}$ & 548 & 478 & 279 & 216 & -269 & -262 \\
\hline Doctors per 10 thousand population, persons & 57 & 53,2 & 25 & 26,3 & -32 & -27 \\
\hline $\begin{array}{l}\text { Medium-grade medical personnel per 10 thousand } \\
\text { population, persons }\end{array}$ & 109,9 & 96,8 & 76,3 & 82,3 & -34 & -15 \\
\hline Hospital beds per 10 thousand population, units & 93,6 & 78,5 & 61 & 62,4 & -33 & -16 \\
\hline $\begin{array}{l}\text { Number of tourists accommodated in collective } \\
\text { accommodation establishments per 1000 } \\
\text { population, persons }\end{array}$ & 283 & 227 & 367 & 594 & 84 & 367 \\
\hline Forests and other wooded areas, \% of the total area & 31,8 & 32,3 & 40,7 & 39 & 9 & 7 \\
\hline Agricultural land,\% of the total area & 59,1 & 56,8 & 52,9 & 54,1 & -6 & -3 \\
\hline Gross regional product, million euros & 5968 & 5514 & 15511 & 19417 & 9543 & 13903 \\
\hline Gross regional product per 1 person, euro & 2350 & 2183 & 7286 & 15400 & 4936 & 13217 \\
\hline
\end{tabular}


The identified different level of social-economic development indicates in general the remoteness of the regions of Ukraine and Poland, which determines the ability to attract investment under the Program and the potential for projects under the Program. It should be assumed that Podkarpackie Voivodeship is more effective in terms of implementing infrastructure projects within the program due to significant social-economic potential, stable GDP growth in the region, higher quality of life and access to more qualified personnel with higher productivity. In order to verify the outlined hypothesis, it is necessary to assess the status of project implementation within the Program.

\subsection{Implementation of the Program's projects}

There are three categories of projects within the Programme. Large infrastructure projects (LIPs) are strategic to ensure regional development lasting up to 36 months with a minimum cost of 2,5 million euros. Regular projects are less than LIPs (minimum cost amounts 100 thousand euros, maximum cost amounts up to 2,5 million euros, duration - up to 24 months) and provide investment in infrastructure, investment activity and other "soft" measures to improve the quality of life. Micro-projects are limited by a small budget in the field of noninvestment activities, providing incentives for citizens' activity. The minimum cost of projects is 20 thousand euros, the maximum - 60 thousand euros, the duration of implementation - up to 12 months. These categories of projects are implemented within the basic directions of the Programme: "Heritage, Accessibility, Security and Borders". Of all the projects, 93 belong to beneficiaries in Poland, 64 - in Ukraine and 49 - in Belarus. The feature of financing LIPs within the Programme is the ownership of assets after the project implementation by state authorities or municipalities. For instance, within the direction 2.1 (Table 2) of the three Poland-Ukraine cooperation projects, the final beneficiaries are Podkarpackie Regional Road Management (PL), Mazowieckie Voivodeship (PL), Lubelskie Voivodeship (PL).

Table 2. Structure of LIPs' funding volumes between Poland and Ukraine, 2019

\begin{tabular}{|c|c|c|c|}
\hline $\begin{array}{c}\text { Large infrastructure } \\
\text { projects }\end{array}$ & 2019 & $\begin{array}{c}\text { PL-UA, } \\
\text { million } \\
\text { euro }\end{array}$ & $\begin{array}{c}\text { The share } \\
\text { of PL-UA } \\
\text { projects, \% }\end{array}$ \\
\hline
\end{tabular}

\begin{tabular}{|l|c|c|c|}
\hline $\begin{array}{l}\text { 2.1 Improvement and } \\
\text { development of transport } \\
\text { services and } \\
\text { infrastructure }\end{array}$ & 21,74 & 17,1 & 78,66 \\
\hline $\begin{array}{l}\text { 3.1 Support to the } \\
\text { development of health } \\
\text { protection and social } \\
\text { services }\end{array}$ & 11,56 & 11,56 & 100,00 \\
\hline $\begin{array}{l}3.2 \text { Addressing common } \\
\text { security challenges }\end{array}$ & 9,46 & 5,4 & 57,08 \\
\hline $\begin{array}{l}\text { 4.1 Support to border } \\
\text { efficiency and security }\end{array}$ & 5,31 & 0 & 0,00 \\
\hline $\begin{array}{l}4.2 \text { Improvement of } \\
\text { border management } \\
\text { operations, customs and } \\
\text { visas procedures }\end{array}$ & 4,05 & 0 & 0,00 \\
\hline \multicolumn{2}{|l|}{ Source:2 25$]$} & & \\
\hline
\end{tabular}

Source: [2; 25]

Thus, the regions of Poland are implementing large infrastructure projects; consequently, it is possible to confirm the assumption of the importance of regions' similarity in cross-border cooperation in terms of social-economic development in the context of such resources as labor and material ones.

Within the direction 3.1, the beneficiaries are the Health Department of the Regional State Administration of the Transcarpathian Region (UA) and Shatsk District State Administration of Volyn Region (UA). Lviv Regional Board of Administration of the National Police (UA) is the beneficiary of the project in the direction 3.2. Such feature is consistent with the European practice of financing cross-border cooperation, which in fact means the convergence of management policies for financial and economic development of border regions. The share of PL-UA projects is different in different directions. At the same time, in direction 2.1, taking into account the development of projects by the beneficiaries of Poland, the allocated funds fully ensure the development of the country's infrastructure. Projects within direction 3.1 are socially oriented, however we can expect long-term economic effect of cross-border cooperation through improving the health of the population, increasing employment. In fact, there is no funding for the private sector within the Program, projects are socially oriented. Infrastructure and security are priority areas for funding. The social orientation of the projects could ensure a reduction in the unemployment rate in the Subcarpathian Voivodeship from $14,3 \%$ in 2013 to 6,5\% in 2018. In addition, GDP per capita in Poland's voivodeship increased significantly from 7286 EUR in 2013 to 
15400 EUR in 2018, while it remained at the same level in Lviv region: 2350 EUR in 2013 and 2183 EUR in 2018. Herewith, no significant socialeconomic transformations are observed during the Program period in Lviv region.

Funding of the Regular project between Poland and Ukraine (See Table 3) has similar features. The ultimate beneficiaries are local authorities.

Table 3. Structure of funding volumes of Regular project between Poland and Ukraine, 2019

\begin{tabular}{|l|c|c|c|}
\hline \multicolumn{1}{|c|}{ Regular project } & 2019 & PL-UA & $\begin{array}{c}\text { The share } \\
\text { of PL-UA } \\
\text { projects, } \%\end{array}$ \\
\hline $\begin{array}{l}\text { 1.1 Promotion of local culture } \\
\text { and history }\end{array}$ & 19,68 & 11,81 & 60,01 \\
\hline $\begin{array}{l}\text { 1.2 Promotion and } \\
\text { preservation of natural } \\
\text { heritage }\end{array}$ & 13,51 & 8 & 59,22 \\
\hline $\begin{array}{l}\text { 2.1 Improvement and } \\
\text { development of transport } \\
\text { services and infrastructure }\end{array}$ & 30,87 & 13,58 & 43,99 \\
\hline $\begin{array}{l}\text { 2.2 Development of ICT } \\
\text { infrastucture }\end{array}$ & 2,37 & 0 & 0,00 \\
\hline $\begin{array}{l}3.1 \text { Support to the } \\
\text { development of health } \\
\text { protection and social services }\end{array}$ & 17,17 & 4,21 & 24,52 \\
\hline $\begin{array}{l}\text { 3.2 Addressing common } \\
\text { security challenges }\end{array}$ & 9,55 & 6,68 & 69,95 \\
\hline $\begin{array}{l}\text { 4.1 Support to border } \\
\text { efficiency and security }\end{array}$ & 11 & 6,24 & 56,73 \\
\hline $\begin{array}{l}\text { 4.2 Improvement of border } \\
\text { management operations, } \\
\text { customs and visas procedures }\end{array}$ & 9,09 & 6,86 & 75,47 \\
\hline Source: 2 $25 ; 261$ & & \\
\hline
\end{tabular}

Source: $[2 ; 25 ; 26]$

In the structure of projects, financing of infrastructure development prevails (both in general and between Poland - Ukraine) with shares of $27 \%$ and 24\%, respectively (direction 2.1). The promotion of history and culture, natural heritage, health care, security and border efficiency are the priorities of the Programme. Herewith, the development of ICT infrastructure (direction 2.2) is practically not funded.

The analysis of management and financing of development projects of border regions within the framework of the Poland-Ukraine Cooperation Programme makes it possible to form one important conclusion. Local authorities ensure social development by improving the quality of public services (education, health care, transport infrastructure) within the Cooperation Program, integration of EU practice. The funding is taking place of those social spheres, the development of which is regulated by the state at the national level in the transition to the market. This is in line with the market model of the economy. In the long run, this will ensure high social development, improving the quality of life, increasing employment, and as a result - investment growth. Indicators of socialeconomic development of Podkarpackie Voivodeship demonstrate the effectiveness of the program, while in Lviv region there is no evidence of a significant impact of the program on the development of the region.

\subsection{The impact of cross-border cooperation on the investment attractiveness of regions}

In order to assess the impact of cross-border cooperation on the investment attractiveness of regions, the dynamics of foreign direct investment from Poland to Ukraine has been used. In general, the dynamics of direct investment (share capital) from Poland to the Lviv region in 2015-2019 (Table 4) is inconsistent and chaotic. The share of Polish FDI in the Lviv region decreased from $28 \%$ in 2013 to $18,83 \%$ in 2019. It is obvious that the implementation of the Program in the short term does not increase the investment attractiveness of border regions in Ukraine due to inefficient management of financial and economic development. Along with this, indicators of the development of the Polish voivodship indicate the presence of positive effects in the form of improving the quality of life.

Table 4. Dynamics of direct investments (share capital) from Poland to Lviv region in 2015-2019

\begin{tabular}{|l|c|c|c|c|c|c|c|c|}
\hline \multirow{2}{*}{ Indicator } & \multicolumn{7}{|c|}{ Volumes of investments as of January 01 } \\
\cline { 2 - 9 } & 2013 & 2014 & 2015 & 2016 & 2017 & 2018 & 2019 & 2020 \\
\hline Direct investment (share capital), mln. USD & 378,63 & 402,00 & 271,43 & 282,77 & 111,36 & 133,38 & 166,52 & 210,25 \\
\hline Share,\% & 28,77 & 29,14 & 24,73 & 27,38 & 13,36 & 14,34 & 17,57 & 18,83 \\
\hline Absolute deviation, +/- & & 23,36 & $-130,56$ & 11,34 & $-171,42$ & 22,02 & 33,14 & 43,73 \\
\hline Growth rate, \% & & $6,17 \%$ & $-32,48$ & 4,18 & $-60,62$ & 19,77 & 24,85 & 26,26 \\
\hline
\end{tabular}

Source: [27] 
For instance, in 2015 the growth rate of direct investment was $4,18 \%$, in 2017 there was a decrease of $60,62 \%$, in 2019 - an increase of $26,26 \%$ (see Table 4). Obviously, it is difficult to trace the link between development finance and investment in the border regions of Poland and Ukraine. Nevertheless, the formation of industrial parks has been launched in Lviv region, which, provided the quality of life of the population improves, it will ensure synergy and economic development of the regions, taking into account all components of sustainable development. This prerequisite can ensure the formation of investment attractiveness of Lviv region and the inflow of FDI from Poland. There are industrial parks on the territory of Lviv region: "Ryasne-2" (the city of Lviv; management company) and "Sigma Park Yarychiv" (the village of Staryi Yarychiv, Kamyanka-Buzka district, Lviv region). The following projects, involving the creation of industrial parks, are in the process of implementation: Kamyanka-Buzka Industrial Park (the city of Kamyanka-Buzka, Lviv region), Yavoriv Industrial Park (Yavoriv District, Lviv Region) and Novorozdil Industrial Park (the city of Novy Rozdil, Lviv Region). The development of the infrastructure of industrial parks through the financing of projects, the creation of conditions for full functioning takes place within the action plans for the implementation of the regional development strategy at the expense of the State Fund for Regional Development [28], in accordance with the Budget Code of Ukraine, sectoral support from EU funds and subventions for the creation of ATC infrastructure [29].

For instance, the State Fund for Regional Development funds the project of construction of engineering and transport infrastructure of the Industrial Park in Kamyanka-Buzka, Lviv region with the preparation of design and estimates documentation in the amount of 14514,765 thousand UAH, in particular 12337,55 thousand UAH - at the expense of the State Fund for Regional Development and 2 177,215 thousand UAH - at the expense of local budgets [29]. Herewith, there is no funding from partners or international organizations.

\section{Discussions}

The present investigation significantly correlates with the results of the study of cross-border cooperation in various areas: governance, cooperation, economic development and mobility. Similar to the findings of Makkonen \& Williams on the lack of in-depth investment research as a positive outcome of cross-border cooperation, this study also proves that investments remain little studied due to the difficulty of analyzing long-term effects, the lack of comparable data on the amount of funding for cooperation projects and investment growth [23]. At the same time, $\mathrm{Hu}, \mathrm{Li} \&$ Qin have proven the growth of investment as a result of the integration of the regions of two countries [7].

This study proves the position of Bakushevich et al. [1] Studzieniecki [9], \& Dobina [22] that international projects of regional development and territorial cooperation are effective tools of integration and financing of development of border regions. At the same time, the results obtained do not confirm Nagy's assumption that the financing of cross-border cooperation from EU funds does not lead to an increase in local budgets [19]. Analysis of border development projects under the PolandUkraine Cooperation Program shows that local authorities have been given more opportunities for social development by improving the quality of public services (education, health care, transport infrastructure) both within cooperation and through learning EU countries.

This research has also revealed that socially oriented costs increase with the financial and economic development of border regions [16]. This is due to the funding of social projects. As the practice of cross-border cooperation between Poland and Ukraine shows, local authorities are the beneficiaries of the implemented projects; consequently, cross-border development is socially oriented in the first place and can ensure economic development only indirectly in the long run period. Beneficiaries are responsible for ensuring a high level of quality of life; thereby, local governments invest in the welfare of the population (health care, medicine, transport and other types of infrastructure). As mentioned by Kuépié, the private sector aims to make a profit, the state expects the growth of social-economic development [18]. Fully agreeing with this position, it can be mentioned that, cross-border cooperation is aimed at improving the quality of life through the social sphere, where the state is the main regulator of public services. Regional economic development of border areas is provided indirectly through the growth of welfare. Similar findings have been revealed in the study of Cappellano \& Rizzo, where the positive effects of cross-border cooperation are noted in the presence of a talented workforce [17]. This means that the formation of human capital is ensured through social development. Financing of the social sphere through investments in health care, infrastructure and other social directions ensures the development of a quality workforce. As a result, the quality of 
human capital in the long run period will determine the level of investment and innovation in border regions. "Innovations are key factor in long-term economic development of the region" [14].

Klatt summarized that systemic differences reduce cooperation [9] and present research confirms this conclusion. Ukraine and Poland are characterized by different levels of social-economic development of the territories. As a result, the level of cooperation is low, which is reflected in the predominance of the implementation of infrastructure projects in Poland, while Ukraine's projects are socially oriented. The level of synergy could be higher provided that the level of disparities between regional development is reduced.

Similar to the findings of Günther, Latifi, Lubacha-Sember \& Töbelmann [8], the present investigation proves that in general the intensity and frequency of joint research activities within the cooperation of regions between countries is much higher; it provides opportunities for future integration with potential positive consequences for economic development. Our study also proves that despite the direction of cooperation between border regions, in general, integration provides indirect long-term effects.

\section{Conclusion}

The hypothesizes concerning the crucial role of the proximity of border regions in the level of development of the social-economic system has been proven in this study; it accelerates cross-border cooperation and the effects of integration.

Research and assessment of funding of the Cross-border Cooperation Programme PolandBelarus-Ukraine 2014-2020 proves that there are insignificant short-term effects of cooperation between countries due to the different level of development of the border regions of Ukraine and Poland. The higher level of economic development of the regions of Poland has provided a comparative advantage in the implementation of projects under the Programme. On the other hand, the relatively lower level of financial and economic development of the border areas of Ukraine has led to a significant lag in the implementation of projects. As a result, positive indirect results of integration will be provided in various directions in the long run period. Another important conclusion is that the management of financial and economic development of border regions is carried out through the financing of those social spheres, the development of which is regulated by the state at the national level within the conditions of transition to the market. This corresponds to the market model of the economy. In the long run perspective, this will ensure high social development, improving the quality of life, employment growth, and as a result investment growth.

The practical significance of the results lies in the possibility of using the results of the study in the development of cross-border cooperation programs within the new concept of "cross-border regional innovation system". Prospects for further research are to study the impact of cross-border cooperation on migration processes in border areas and prospects for future membership of Ukraine in the EU.

\section{References:}

[1] Bakushevych, I., Goshchynska, D., Martyniak, I. Decentralization and Innovative Enterpreneurial Ecosystem development for the EU-Ukraine Cross-border Cooperation. The Balanced Development of National Economy Under the Conditions of Modern World Transformation. Monograph. 2019, pp.139152. Daugavpils.

[2] European Union. Facts and figures. The ENI cross-border cooperation programe Poland Belarus - Ukraine 2014-2020. 2020. Retrieved from

https://www.pbu2020.eu/files/librarynews/file/ 484e 07b8-2ce0-4a54-a8cc-

52bf06edec57/Fact\&Figures_aktualizacja_12_ 2019.pdf

[3] Makkonen, T., \& Williams, A. M. Border region studies: The structure of an 'offbeat'field of regional studies. Regional Studies, Regional Science, 3(1), 2016, pp. 355367. doi:10.1080/21681376.2016.1209982

[4] Bakulina, O., Lehan, I., \& Bakhov, I. Cluster associations as a factor of innovative and integrative development of the economy. International Journal of Innovative Technology and Exploring Engineering, 8(10), 2019, pp. 2249-2255. doi:10.35940/ijitee.J1122.0881019

[5] Holovatyi, M. Multiculturalism as a means of nations and countries interethnic unity achieving. Economic Annals-XXI, 11-12, 2014, pp. 15-18.

[6] Hameiri, S., Jones, L., \& Zou, Y. The development-insecurity nexus in China's nearabroad: Rethinking cross-border economic integration in an era of state transformation. Journal of Contemporary Asia, 49(3), 2019, pp. 473-499. https://doi.org/10.1080/00472336.2018.150280 2 
[7] Hu, Y., Li, C., \& Qin, C. The impact of regional financial depth on outbound crossborder mergers and acquisitions. Journal of International Money and Finance, 2020, 102181. 10.1016/j.jimonfin.2020. 102181

[8] Günther, J., Latifi, G., Lubacha-Sember, J., \& Töbelmann, D. Scientific Cooperation in a German Polish Border Region in the Light of EU Enlargement. Foresight and STI Governance, 11 (1). 2017, pp. 42-53. http://dx.doi.org/10.17323/25002597.2017.1.42.53.

[9] Klatt, M. The so-called 2015 migration crisis and Euroscepticism in border regions: Facing re-bordering trends in the Danish-German borderlands. Geopolitics, 25(3), 2020, pp. 567586.

https://doi.org/10.1080/14650045.2018.155714 9

[10] Iatsyshyn, A. V., Kovach, V. O., Romanenko, Y. O., \& Iatsyshyn, A. V. Cloud services application ways for preparation of future $\mathrm{PhD}$. Paper presented at the CEUR Workshop Proceedings, 2433, 2019, pp. 197-216.

[11] Studzieniecki, T. The development of crossborder cooperation in an EU macroregion-a case study of the Baltic Sea Region. Procedia Economics and Finance, 39, 2016, pp. 235$241 . \quad$ https://doi.org/10.1016/S22125671(16)30318-5

[12] Pawlewicz, K., Senetra, A., GwiaździńskaGoraj, M., \& Krupickaite, D. Differences in the environmental, social and economic development of Polish-Lithuanian trans-border regions. Social Indicators Research, 147(3), 2020, pp. 1015-1038. https://doi.org/10.1007/s11205-019-02179-9

[13] Mendoza, J. E., \& Dupeyron, B. (). Economic Integration, Emerging Fields and Cross-border Governance: The Case of San DiegoTijuana. Journal of Borderlands Studies, 35(1), 2020, $\quad$ pp. 55-74. https://doi.org/10.1080/08865655.2017.136771 1

[14] Lavrinenko, O., Jefimovs, N., \& TeivānsTreinovskis, J. (). Issuies in the area of secure development: trust as an innovative systems economic growth factor of border regions (Latvia-Lithuania-Belarus). Journal of Security \& Sustainability Issues, 6(3). 2017, pp. 79-86. https://doi.org/10.9770/jssi.2018.8.1(7)

[15] Mikhaylov, A. S., Mikhaylova, A. A., \& Savchina, O. V. Innovation security of crossborder innovative milieu. The International Journal Entepreneurship ansd sustainability issues, 6 (2), 2018, pp. 755-765. http://doi.org/10.9770/jesi.2018.6.2(19)

[16] Krivonosova, N. Trends and features of budget financing of the border regions of the Siberian Federal District. In International Conference on Sustainable Development of Cross-Border Regions: Economic, Social and Security Challenges (ICSDCBR 2019). Atlantis Press.

[17] Cappellano, F., \& Rizzo, A. Economic drivers in cross-border regional innovation systems. Regional Studies, Regional Science, 6(1), 2019, pp. 460-468. https://doi.org/10.1080/21681376.2019.166325 6

[18] Kuépié, M., Tenikue, M., \& Walther, O. J. Social networks and small business performance in West African border regions. Oxford Development Studies, 44(2), 2016, pp. 202-219. https://doi.org/10.1080/13600818.2015.108254 0

[19] Nagy, I. Cross-border cooperation on the external borders of the EU and the impact of the received EU CBC funds on AP Vojvodina/Serbia. Belgeo. Revue belge de géographie, $2,2020$. https://doi.org/10.4000/belgeo.38732

[20] Shvets, V. Y., Rozdobudko, E. V., \& Solomina, G. V. Aggregated methodology of multicriterion economic and ecological examination of the ecologically oriented investment projects. Naukovyi Visnyk Natsionalnoho Hirnychoho Universytetu, 3, 2013, pp. 139-144.

[21] Romanenko, Y. O., \& Chaplay, I. V. Marketing communication system within public administration mechanisms. Actual Problems of Economics, 178(4), 2016, pp. 69-78.

[22] Dobina, T., Haidukevych, K., Panchenko, S., Petrova, I., \& Sabadash, J. Effectiveness analysis of entrepreneurship model of development qualities of future managers. Journal of Entrepreneurship Education, 22(3), 2019.

[23] Makkonen, T., Williams, A. M., Mitze, T., \& Weidenfeld, A. Science and technology cooperation in cross-border regions: A proximity approach with evidence for Northern Europe. European Planning Studies, 26(10), 2018, pp. 1961-1979. https://doi.org/10.1080/09654313.2018.150052 8

[24] PBU. Cross-border Cooperation Programme Poland-Belarus-Ukraine 2014-2020. Retrieved from https://www.pbu2020.eu/ua 
[25] PBU. Regular projects. Cross-border Cooperation Programme Poland - Belarus Ukraine 2014-2020. Retrieved from https://www.pbu2020.eu/files/librarynews/file/ c17c2e26-94bc-4940-99e2-

246885e1c8c0/Regular_Projects_2020_www.p df

[26] PBU. The Cross-borderer. 2019 edition. Retrieved from https://www.pbu2020.eu/files/librarynews/file/ $345 \mathrm{a} 2 \mathrm{fe} 3-\mathrm{e} 75 \mathrm{c}-4 \mathrm{~d} 2 \mathrm{c}-90 \mathrm{e} 0-$ 9e2e9a51c3b3/2019.pdf

[27] Main Department of Statistics in Lviv Region. The main indicators of cross-border regions 2020.

http://database.ukrcensus.gov.ua/statbank_lviv/ Dialog/Saveshow.asp

[28] State Fund for Regional Development. List of projects in the field of industrial and innovation parks 2020. Retrieved from http://dfrr.minregion.gov.ua/Projects-list

[29] The Ministry of Economic Development, Trade and Agriculture of Ukraine). Information about industrial parks in Ukraine, 2020. Retrieved from https://www.me.gov.ua/Documents/Detail?lang =uk-UA\&id=45629531-ea5f-4a91-9050-

fe47b001dc22\&title=DovidkaProIndustrialniPa rkiVUkraini

\section{Creative Commons Attribution}

\section{License 4.0 (Attribution 4.0}

\section{International, CC BY 4.0)}

This article is published under the terms of the Creative Commons Attribution License 4.0 https://creativecommons.org/licenses/by/4.0/deed.en _US 